\title{
PROFIL PERAN ORANG TUA DAN GURU DALAM PENYIAPAN MASA TRANSISI ANAK KE SEKOLAH DASAR
}

\author{
Lia Dwi Ayu Pagarwati* \\ Lantip Diat Prasojo \\ Sugito \\ Arif Rohman \\ Program Pascasarjana, Pendidikan Anak Usia Dini, Universitas Negeri Yogyakarta \\ J1. Colombo No.1 Yogyakarta, Indonesia \\ *E-mail: liadwi.2019@student.uny.ac.id
}

Artikel diterima: 15 September 2020; disetujui: 11 Mei 2021

\begin{abstract}
The purpose of this study is to describe the role of teachers (SD \& TK) and parents in preparing for the transition period of children to elementary school in Kecamatan Air Sugihan. This research uses descriptive quantitative research with a survei method. Respondents in this study were 7 first grade elementary school teachers, 11 kindergarten teachers, and 89 parents of students. The study results indicate that child development is not optimal and environmental changes are the main problems in the transition period of children so that the roles of teachers (SD \& kindergarten) and parents play an essential role in the transition period of children to produce optimal school readiness. This role is in the form of responsibility for children's school readiness, as a motivator for children, as a role model, as a supervisor and as a place to ask children so that all the needs of children's school readiness are met.
\end{abstract}

Keywords: the role of teachers and parents; transition period; primary school

\begin{abstract}
Abstrak: Tujuan penelitian ini untuk menggambarkan peran guru (SD \& TK) dan orangtua dalam penyiapan masa transisi anak ke sekolah dasar di kecamatan Air Sugihan. Penelitian menggunakan penelitian kuantitatif deskriptif dengan metode survei. Responden dalam penelitian ini 7 orang guru kelas I SD, 11 orang guru TK, dan 89 orangtua siswa. Hasil dari penelitian menunjukkan bahwa perkembangan anak yang belum optimal dan perubahan lingkungan merupakan masalah utama dalam masa transisi anak sehingga peran guru (SD \& TK) dan orangtua sangat berperan penting dalam hal masa transisi anak agar menghasilkan kesiapan bersekolah yang optimal. Peran tersebut berupa tanggung jawab terhadap kesiapan sekolah anak, motivator bagi anak, sebagai panutan, sebagai pengawas dan sebagai tempat bertanya anak sehingga semua kebutuhan dalam kesiapan sekolah anak terpenuhi.
\end{abstract}

Kata kunci: peran guru dan orangtua; masa transisi; sekolah dasar

\section{PENDAHULUAN}

Masa transisi sering diartikan sebagai masa peralihan dari segi lingkungan dan fase kehidupan manusia (Pirskanen dkk., 2019). Masa transisi tersebut bisa dirasakan dalam jenjang pendidikan dan jabatan dalam profesi, contoh dalam dunia anak TK. Saat anak melanjutkan pendidikannya ke 
sekolah dasar anak akan mengalami masa tersebut. Dimana lingkungan anak TK yang tadinya berbasis belajar sambil bermain akan berubah dengan segala keseriusannya dengan berbasis tugas individual. Dalam perkembangannya, anak pun juga mengalami transisi, seperti dari segi perkembangan sosial emosional. Anak akan dituntut lebih bertanggung jawab dalam menyelesaikan tugas tanpa bantuan orang dewasa (guru dan orang tua), lingkungan bersosialisasinya akan bertambah luas sehingga harus membangkitkan kemampuan komunikasi yang baik dari segi bahasa, membutuhkan kekuatan otot tangan dan koordinasi mata serta proses berpikir yang lebih matang. Untuk itu perlunya lingkungan yang mendukung dalam persiapan yang matang bagi anak untuk menghadapi masa tersebut.

Berkaitan dengan persiapan tersebut, pada faktanya, di lapangan banyak ditemukan beberapa hambatan dalam penyiapan masa transisi anak misalnya saja dari segi orang tua seperti latar belakang pendidikan, kondisi ekonomi, dan jenis kelamin. Menurut Jafarov (2015) hambatan yang mempengaruhi keterlibatan orang tua yaitu dipengaruhi oleh beberapa faktor sosial-politik, seperti kondisi sosial ekonomi dan pengalaman sekolah yang negatif dari orang tua. Hal ini sejalan dengan pendapat yang yang menegaskan bahwa latar pendidikan orang tua memiliki capaian yang menentukan apakah orang tua akan terlibat aktif dalam kegiatan anak-anak Donoghue dalam (Magwa \& Mugari, 2017). Bagi beberapa orang tua yang memiliki pendidikan rendah, bukan berarti tidak tertarik untuk terlibat dirinya dalam pendidikan anak, tetapi orangtua tidak memiliki pengetahuan yang cukup tentang apa yang dimaksud dengan keterlibatan orang tua, dan bagaimana cara terlibat dalam pendidikan anak-anak mereka tidak seperti orangtua yang berpengetahuan luas. Seperti halnya yang terjadi dilapangan terkadang orang tua bingung dan merasa kesal menghadapi atau mendampingi pada saat anak belajar. Pendapat lain yaitu dari LaRocque et al dan Lee \& Bowen dalam (McDowell dkk., 2018) tingkat pendidikan orang tua juga dapat menjadi penghalang bagi keterlibatan dalam anak-anak mereka dalam berprestasi.

Orang tua mungkin tidak menempatkan nilai dalam pendidikan karena pendidikan mereka sendiri atau kurangnya keberhasilan sekolah sendiri. Orang tua mungkin memiliki pandangan negatif tentang sekolah dari mereka pengalaman sendiri. Hal ini dapat menyebabkan penghindaran sekolah, yang mungkin terkait dengan keragu-raguan mereka untuk bertanya kepada guru atau sekolah karena mereka merasa rendah diri. Selain itu, keutuhan keluarga juga berpengaruh pada keterlibatan orang tua. Sebuah hasil penelitian menunjukkan bahwa orang tua yang menikah lebih banyak terlibat dari pada orang tua yang bercerai (Lau dkk., 2012). Banyak pembahasan mengenai jenis kelamin orang tua (ayah atau ibu) itu memiliki dampak pada pendidikan anak. Seperti pendapat Eagle dalam (Hartlep \& Ellis, 2010) bahwa mungkin ada kesesuaian gender atau gagasan bahwa keterlibatan orang tua, dan juga keterikatan terjadi antara jenis kelamin yang identik (misalnya, ayah yang terlibat dengan anak laki-laki, dan ibu terlibat dengan anak perempuan dan terkait studi yang hasilnya menunjukkan bahwa 
ayah terlibat dalam lebih banyak interaksi dengan putra mereka dari pada putri mereka (Burns \& Homel, 1989; Cote \& Azar, 1997; Lubbe, 2007; Muntoni \& Retelsdorf, 2019).

Berkaitan dengan aspek guru, terdapat beberapa hambatan seperti tidak adanya program untuk penyiapan masa transisi di lembaga tempat mengajar dan sulitnya berkomunikasi dengan wali murid. Seperti dari hasil-hasil penelitian yang dilakukan sebelumnya, yaitu menunjukkan adanya perbedaan pemahaman antara orang tua, anak dan guru mengenai konsep kesiapan bersekolah dan transisi positif ke sekolah Brandt \& Gracet et.al dalam (Nurhayati, 2018). Pemahaman orang tua disini cenderung menganggap transisi ke sekolah akan berjalan lancar bila ada dukungan untuk kesiapan kemampuan anak yang berkaitan dengan kesiapan perkembangan sosio-emosi, motorik dan bahasa (Barth \& Parke, 1993; Dockett \& Perry, 2004). Dari permasalah tersebut, bisa kita lihat sangat perlunya kolaborasi antara guru dan orang tua agar bisa berperan aktif dalam mempersiapkan masa transisi anak agar berjalan dengan optimal (Correia \& Marques-Pinto, 2016).

Vygotsky juga memaparkan dalam teori konsep Zone of Proximal Development (ZDP sebagai "jarak antara tingkat pengembangan aktual yang ditentukan oleh pemecahan masalah independen dan tingkat pengembangan potensial sebagaimana ditentukan melalui pemecahan masalah di bawah bimbingan orang dewasa atau dalam kolaborasi dengan rekan yang lebih mampu" (Yu dkk., 2013). Orang merupakan orang yang terlibat dalam proses membantu anak yang kontribusinya sangat berperan dalam pendidikan anak usia dini, yang mana pendidikan pertama diperoleh dari lingkungan keluarga yaitu orang tua. Hal tersebut seperti yang dikatakan oleh Wanat dalam (Kocayörük, 2016), jelas bahwa orang tua dapat membantu anak-anak menjadi lebih sukses di sekolah dengan meningkatkan keterlibatan keluarga dalam mengatasi hambatan khusus untuk belajar dan keikutsertaan orang tua memiliki pengaruh positif dan langsung yang penting terhadap kinerja akademik siswa.

Terkait teori yang dipaparkan Vygotsky tersebut orang dewasa bisa juga selain orang tua, yaitu bisa saja guru dan orang-orang terdekat anak. Dimana guru merupakan orang yang dipercaya anak dalam luar lingkungan keluarga. Guru sebagai pendidik anak dilingkungan sekolah juga sangat berperan dalam persiapan masa transisi tersebut. Hal tersebut sejalan dengan penelitian Belsky et al. dalam (Angel \& Garcia, 2014), menunjukkan bahwa ketika interaksi guru-anak yang berkualitas tinggi maka kosakata anak meningkat secara signifikan. Dengan begitu membuktikan bahwa peran guru dalam mendampingi anak mempersiapkan masa transisi anak sangat dibutuhkan. Dengan kata lain, orang tua dan guru sama-sama memiliki peran yang sama dalam pendampingan belajar anak.

Berdasarkan uraian diatas, penting untuk meninjau terkait dengan penyiapan masa transisi anak dari taman-kanak-kanak ke sekolah dasar dari berbagai perspektif. Oleh sebab itu, penelitian ini akan memaparkan informasi mengenai gambaran dari peran guru dan orang tua mengenai penyiapan masa transisi anak ke sekolah dasar di kecamatan Air Sugihan. 


\section{METODE}

Metode dalam penelitian ini menggunakan survei dengan pendekatan penelitian deskriptif kuantitatif. Metode penelitian survei dipilih untuk memperoleh informasi berupa pandangan guru dan orang tua dalam perannya menyiapkan masa transisi anak ke sekolah dasar. Metode survei merupakan suatu metode dimana dalam pengumpulan datanya bisa menggunakan kuesioner dan wawancara yang didapat dari sampel berupa orang, yang mana dari data tersebut akan dapat mewakili suatu populasi tertentu sesuai dengan kepentingan penelitian, baik untuk mengetahui siapa mereka, apa yang mereka pikir, rasakan, atau kecenderungan suatu tindakan (Islamy, 2019). Responden dalam penelitian ini berjumlah sebanyak 7 orang guru sd dari 6 SD, 11 Guru TK dari 8 TK dan 89 orang tua dari 8 TK di Kecamatan Air Sugihan. Responden yang memberikan jawaban berasal dari guru sekolah dasar, guru taman kanak dan orang tua yang memiliki anak TK B yang berada di Kecamatan Air Sugihan.

Instrumen dalam penelitian ini menggunakan kuesioner untuk mengetahui persepsi guru, kepala sekolah dan orang tua terkait masa transisi dari prasekolah ke sekolah dasar yang diadaptasi dari Garcia (2014). Data penelitian ini diperoleh dengan menggunakan tiga kuesioner yaitu kuesioner untuk guru SD terdiri dari tiga aspek yaitu masalah perkembangan anak (12 konten pertanyaan), peran guru pada masa transisi ( 8 konten pertanyaan) dan program masa transisi sekolah (1 konten pertanyaan), kuesioner untuk guru TK terdiri dari dua aspek yaitu peran guru TK pada masa transisi anak (11 konten pertanyaan) dan tentang program masa transisi berisi 2 konten pertanyaan dan kuesioner untuk orangtua tentang keterlibatan orangtua dalam masa transisi anak TK ke SD berisi 6 konten pertanyaan.

Instrumen penelitian ini telah divalidasi oleh beberapa ahli materi melalui tahapan expert judgement kemudian dianalisis menggunakan analisis Aiken dan hasilnya menunjukkan bahwa ketiga kuesioner memiliki indeks Aiken sebesar 1,00 yang berarti tiga kuesioner yang digunakan valid. Adapun uji reliabilitas pada penelitian ini menggunakan bantuan program SPSS versi 22 yang hasilnya menunjukkan pada kuesioner yang ditujukan guru SD sebesar 0,233(>0,05), kuesioner yang ditujukan guru TK menunjukkan hasil sebesar 0,650 $(>0,05)$ dan kuesioner yang ditujukan orangtua menunjukkan hasil sebesar $0,533(>0,05)$ yang berarti tiga kuesioner tersebut reliable. Setelah kuesioner dinyatakan valid dan reliabel, kuesioner disebar kepada responden guna untuk memperoleh gambaran tentang peran orang tua dan guru (TK \& SD) dalam penyiapan masa transisi anak ke sekolah dasar. Kemudian, data yang diperoleh dianalisis menggunakan analisis deskriptif untuk menarasikan hasil survei yang dilakukan. 


\section{HASIL DAN PEMBAHASAN}

Penelitian ini memaparkan informasi berupa gambaran dari peran guru SD, guru TK, dan orang tua dalam penyiapan masa transisi anak ke sekolah dasar di kecamatan Air Sugihan.

\section{Peran Guru SD}

Responden yang diambil dari 7 guru SD yang berbeda. Jumlah sampel diambil dari 30\% SD negeri yang berada di lingkungan Kecamatan Air Sugihan, Kabupaten Ogan Komering Ilir, Kota Palembang, Sumatera Selatan. Pada Tabel 1 disajikan data terkait dengan demografis responden guru SD yang terlibat. Secara keseluruhan dapat dinyatakan bahwa hampir seluruh responden berjenis kelamin perempuan karena hanya satu guru laki-laki yang terlibat. Adapun untuk latar belakang pendidikan, seluruhnya merupakan lulusan dari jenjang strata 1 program Pendidikan Guru Sekolah Dasar (PGSD) dan seluruhnya juga berstatus PNS.

Tabel 1. Demografis Responden Guru SD

\begin{tabular}{clcc}
\hline No & \multicolumn{1}{c}{ Aspek } & Jumlah & Persentase \\
\hline 1 & Jenis kelamin & & \\
& Perempuan & 6 & $86 \%$ \\
& Laki-laki & 1 & $14 \%$ \\
2 & Latar belakang pendidikan & & \\
& S1 PGSD & 7 & $100 \%$ \\
3 & Instansi sekolah & 2 & $29 \%$ \\
& SDN 1 Timbulharjo & 1 & $14 \%$ \\
& SDN 1 Panggungharjo & 1 & $14 \%$ \\
& SDN 2 Panggung Harjo & 1 & $14 \%$ \\
& SDN 1 Sidorahayu & 1 & $14 \%$ \\
& SDN 1 Sidomakmur & 1 & $14 \%$ \\
& SDN 2 Sidomakmur & 1 & $100 \%$ \\
& Status Kepegawaian & & $0 \%$ \\
& PNS & 7 & \\
& Non-PNS & 0 & \\
\hline
\end{tabular}

Aspek yang perlu diamati yaitu aspek pertama tentang perkembangan anak kelas satu dan aspek kedua peran guru SD dalam penyiapan masa transisi anak ke sekolah dasar dan ketiga program masa transisi. Pada aspek pertama yang berisi tentang perkembangan anak terdapat 12 butir pertanyaan, aspek kedua berisi 8 butir pertanyaan mengenai peran guru dalam penyiapan masa transisi anak ke sekolah dasar dan aspek ketiga berisi 1 butir pertanyaan mengenai program masa transisi.

Berdasarkan data yang terkumpul dari kuesioner yang disebar pada guru SD, diperoleh jawaban yang tergambar pada Gambar 1. Permasalahan yang terjadi pada perkembangan anak kelas satu bahwa permasalahan pada proses akademis anak yang mendapatkan persentase paling tinggi dengan seluruh responden menyatakan setuju. Terkait dengan peringkat kedua dinyatakan oleh permasalah terkait dengan konsentrasi dan respon yang sebanyak 6 dari 7 responden menyatakan kesetujuannya tentang aspek tersebut. Adapun permasalahan paling sedikit dengan lebih dari sebagian responden (7\%) menyatakan setuju yaitu terkait dengan kerjasama, sosialisasi dan emosi. 


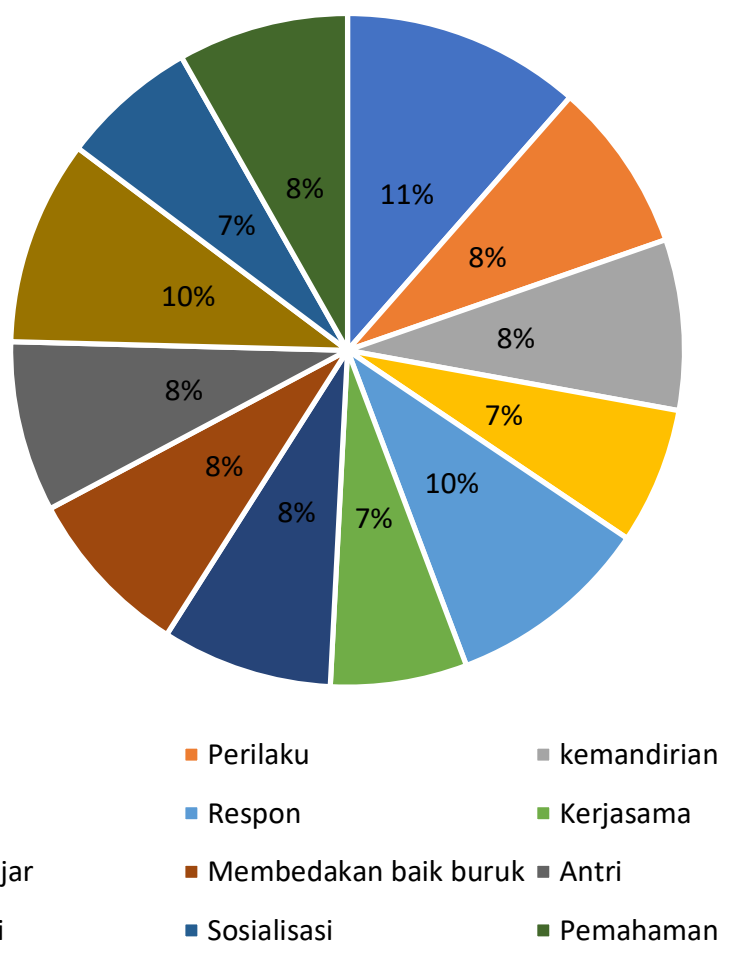

Gambar 1. Permasalahan dalam Perkembangan Anak

Berdasarkan data pada Gambar 1, maka dapat disimpulkan bahwasanya anak pra sekolah yang baru masuk kelas satu masih dikategorikan belum optimal dalam perkembangannya baik dari segi kognitif, sosial emosional, bahasa serta nilai agama dan moral anak. Hal tersebut sejalan dengan pendapat Bruwer, Hartell \& Steyn dalam (Deliviana, 2017) memaparkan bahwa anak usia 5-6 tahun yang berada pada awal sekolah akan mengalami kesulitan dalam belajar karena ketidaksiapan mereka bersekolah dan mengalami resiko dalam lingkaran kesulitan belajar, menampilkan perilaku anti-sosial, dan bisa-bisa menghindar dari lingkungan sekolah karena takut. Sedangkan menurut Sulistyaningsih \& Haditono (1998) dalam hasil penelitiannya yang menunjukkan anak yang belum memiliki kesiapan perkembangan yang optimal akan mengalami kondisi seperti frustasi pada lingkungan akademiknya yaitu mengalami kesulitan menyelesaikan tugas sekolah, memiliki rasa acuh tak acuh, menarik diri dan fisik yang mudah lelah.

Untuk konsep dari kesiapan anak bersekolah sendiri menurut Meisels dalam (Solfiah, 2020) menjelaskan ada empat konsep kesiapan anak usia dini ke sekolah. Dalam perspektif nativisme ataupun teori maturationist, arti dari siap bisa dilihat dari (“...within the child phenomenon"). Maksudnya dari kata tersebut adalah dalam proses terbentuknya kesiapan belajar pada diri anak usia dini yang akan berpengaruh pada kesiapan anak. hal tersebut, mengakibatkan pada kesiapan anak usia dini tergantung kepada proses kematangan perkembangan anak yang mencapai pada tahap yang seharusnya dalam diri anak. 

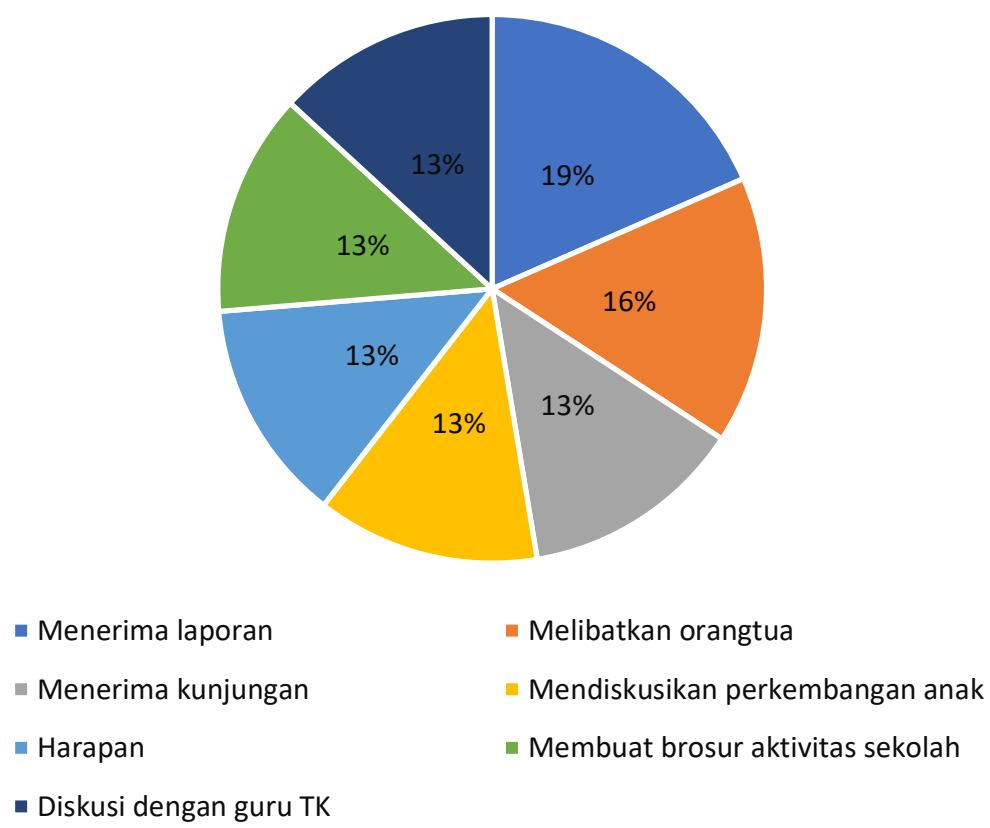

Gambar 2. Peran Guru SD pada Masa Transisi Anak

Konten kedua yaitu tentang peran guru dalam penyiapan masa transisi anak ke sekolah dasar disajikan pada Gambar 2. Berdasarkan data pada Gambar 2, secara garis besar dapat diketahui bahwa hampir seluruh responden telah mengaktifkan peran guru SD dalam masa transisi anak dengan seluruh responden menyatakan persetujuannya untuk menerima laporan akhir dari orangtua atau guru TK tentang keterampilan akademik dan/atau perkembangan anak dengan persentase sebesar $19 \%$. Adapun data tidak setuju hanya diberikan oleh dua orang responden yang ditunjukkan pada poin $13 \%$ terkait dengan aspek menerima kunjungan dari anak-anak prasekolah dan orang tua mengunjungi sekolah dasar (kelas satu), mendiskusikan perkembangan anak dengan orang tua anak sebelum masuk ke sekolah dasar, menjelaskan kepada orang tua apa yang diharapkan anak untuk dilakukan di kelas satu, menyediakan secara tertulis (surat, brosur, flyer) tentang aktivitas apa saja di sekolah dasar ke keluarga anak-anak prasekolah dan melakukan diskusi dengan guru prasekolah mengenai keterampilan sosial dan akademik untuk mempersiapkan anak-anak untuk sekolah dasar.

Berdasarkan sajian data pada Gambar 3 tentang program masa transisi sekolah, dapat diketahui bahwa sebagian responden menyatakan bahwa sekolahnya mengadakan program transisi (4 responden). Hal ini dilakukan setiap satu semester untuk anak-anak dan orang tua dalam mempersiapkan anak ke sekolah dasar dan pertemuan rutin antara guru kelas satu dan guru prasekolah untuk membahas kontinuitas dalam kurikulum antara prasekolah dan kelas satu. 


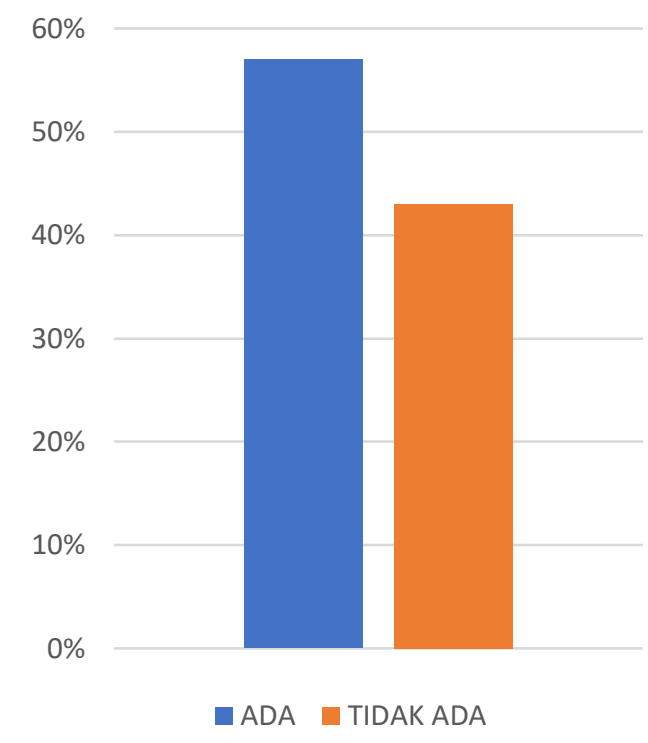

Gambar 3. Program Transisi Sekolah di SD

Berdasarkan data-data yang telah dipaparkan, dapat disimpulkan bahwasanya gambaran peran guru SD dalam mempersiapkan masa transisi anak ke sekolah dasar sangat penting. Seperti yang dipaparkan oleh Damayanti \& Rachmawati (2019) bahwa sangat penting pihak lembaga SD untuk mendampingi anak hingga tercapai kesiapan sekolah yang optimal. Sama halnya dengan penelitian terdahulu yang dilakukan oleh Rahmawati dkk. (2018) yang hasilnya menunjukkan harus adanya kontribusi guru sekolah dasa guna mendukung kesiapan anak untuk bersekolah sehingga menghasilkan transisi yang positif. Selain peran guru juga harus adanya kebijakan dari pemerintah dalam lingkungan pendidikan anak usia dini, seperti kurikulum dari kedua pihak TK dan SD) yang mendukung adanya proses transisi yang positif ini, terutama dalam menjelaskan mengenai panduan kesiapan sekolah dalam transisi ke sekolah. Karena, di lapangan pun yang terjadi hingga saat ini belum ada program khusus mengenai masa transisi ini dari Kementerian Pendidikan dan Kebudayaan.

\section{Peran Guru TK}

Responden yang diambil dari 8 TK yang berbeda yang mengajar pada kelas B (5-6 Tahun). Jumlah sampel diambil dari 30\% TK PGRI yang berada di lingkungan Kecamatan Air Sugihan, Kabupaten Ogan Komering Ilir, Kota Palembang, Sumatera Selatan. Data demografis responden disajikan pada Tabel 2. Secara keseluruhan, seluruh responden guru adalah berjenis kelamin perempuan. Terkait dengan latar belakang pendidikan, dominasi tertinggi jatuh pada lulusan SMA yang mengajar TK dengan hampir mendekati separuh responden (45\%) dan disusul oleh lulusan S1 PGPAUD dan S1 Non-PGPAUD. 
Tabel 2. Demografis Responden Guru SD

\begin{tabular}{clcc}
\hline No & \multicolumn{1}{c}{ Aspek } & Jumlah & Persentase \\
\hline 1 & Jenis kelamin & 11 & $100 \%$ \\
& Perempuan & 0 & $0 \%$ \\
& Laki-laki & & \\
& Latar belakang pendidikan & 5 & $45 \%$ \\
& SMA & 0 & $0 \%$ \\
& D3 & 2 & $18 \%$ \\
& S1 Non PGPAUD & 4 & $36 \%$ \\
& S1 PGPAUD & & \\
& Status Kepegawaian & & $9 \%$ \\
& PNS & 1 & $91 \%$ \\
\hline
\end{tabular}

Untuk mengetahui gambaran dari sisi guru TK, maka dalam penelitian ini peneliti menggunakan kuesioner mengenai peran guru TK dalam penyiapan masa transisi anak ke sekolah dasar yang berisi 13 konten pertanyaan. Berdasarkan data yang terkumpul dari kuesioner yang berisi konten pertanyaan tentang peran guru TK dalam penyiapan masa transisi anak ke sekolah dasar pada Gambar 4.

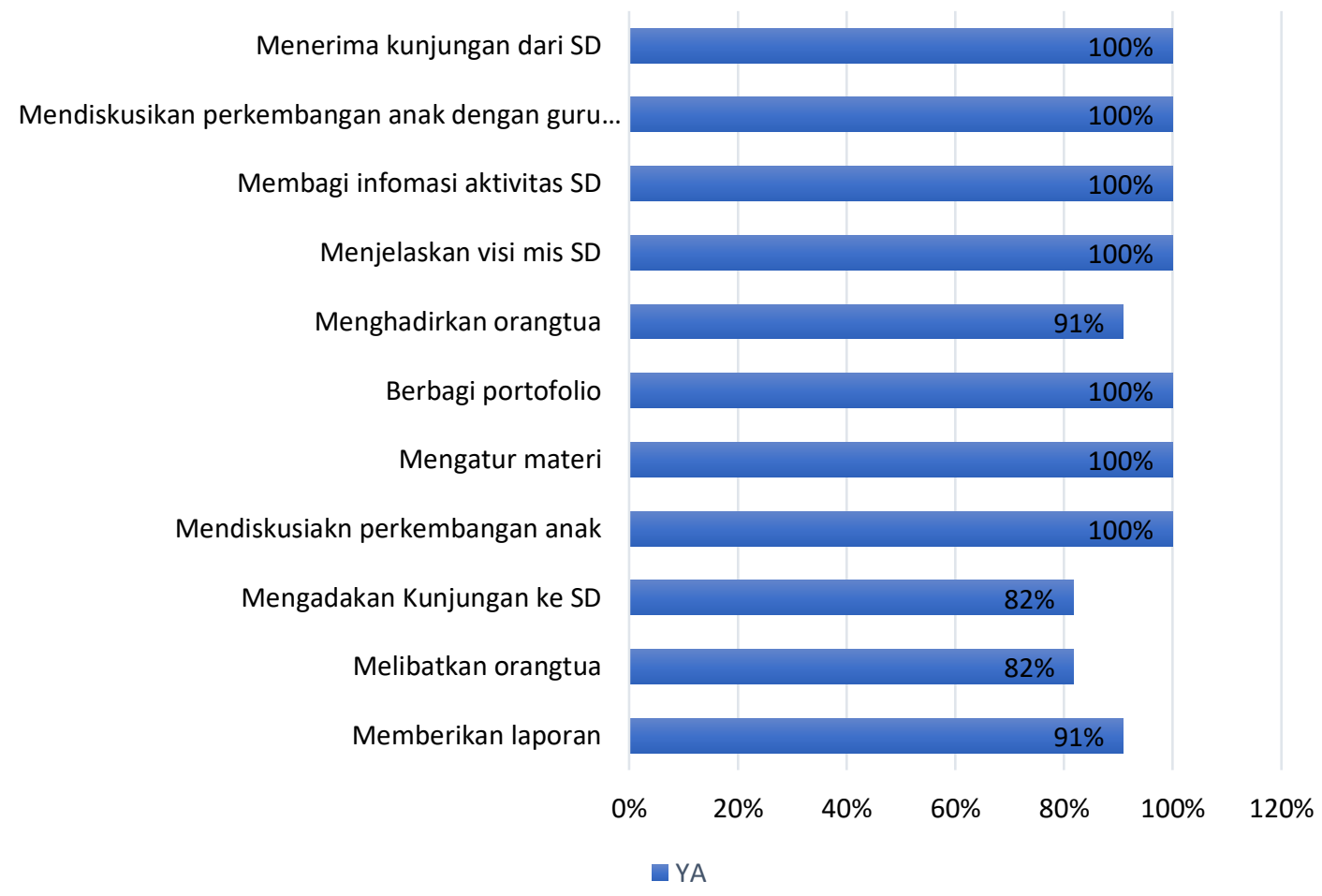

\section{Gambar 4. Peran Guru TK pada Masa Transisi Anak}

Berdasarkan data pada Gambar 3 diketahui bahwa hampir seluruh responden menyatakan setuju pada kegiatan transisi anak ke sekolah dasar terkait dengan peran guru TK. Dalam aspek menghadirkan orang tua dan memberikan laporan yang tidak disepakati oleh satu responden saja. Adapun terkait dengan aspek ketidaksetujuan responden dinyatakan pada poin kunjungan ke sekolah 
dasar dan pelibatan orang tua dalam proses masa transisi. Hal ini menunjukkan bahwa hampir seluruh responden menyatakan bahwa semua peran yang dipaparkan menjadi hal yang penting dalam proses penyiapan anak untuk jenjang berikutnya.

Terkait dengan ada tidaknya program transisi maka digali data terkait program tersebut kepada seluruh responden yang disajikan pada Gambar 5. Berdasarkan data grafik pada gambar lima, hampir seluruh TK PGRI yang ada menunjukkan bahwa mereka belum menerapkan program transisi untuk untuk anak-anak dan orang tua dalam mempersiapkan mereka ke sekolah dasar dan pertemuan rutin antara guru kelas satu dan guru prasekolah untuk membahas kontinuitas dalam kurikulum antara Lembaga TK dan sekolah dasar. Hal ini ditunjukkan dengan data sebanyak 73\% atau 8 sekolah yang menyatakan tidak memiliki program masa transisi sekolah dan hanya 3 sekolah yang sudah menerapkan sejauh ini.

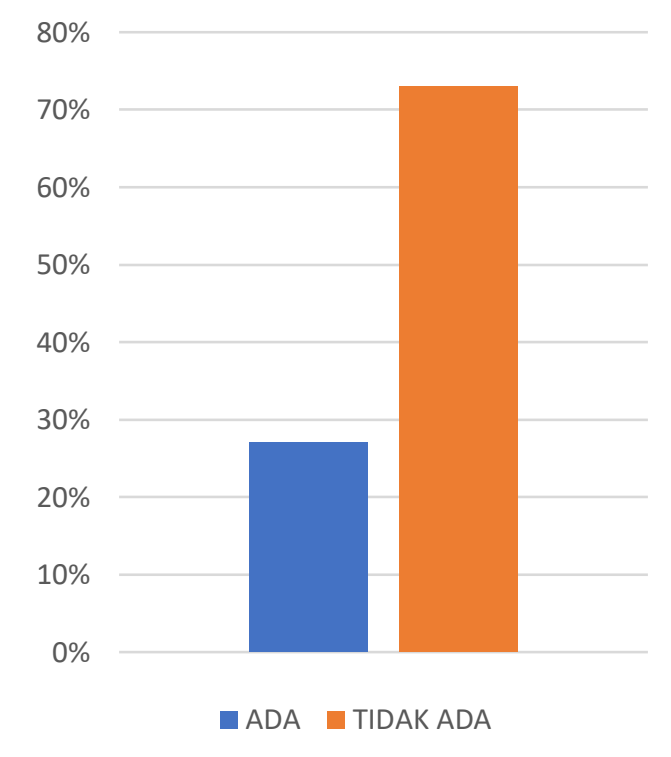

\section{Gambar 5. Program Transisi Sekolah di TK}

Berdasarkan paparan data, dapat disimpulkan bahwasanya gambaran peran guru TK dalam mempersiapkan masa transisi anak ke sekolah dasar sangat penting dalam mempersiapkan kematangan perkembangan anak secara optimal agar siap dalam menghadapi masa transisi. Hal tersebut selaras dengan hasil penelitian dari (Rifai \& Fahmi, 2017) yang menunjukkan hasil bahwa anak taman kanak-kanak yang sudah memiliki kesiapan belajar yang baik untuk bisa masuk ke sekolah dasar dilatar belakangi oleh kerja keras guru dalam menyiapkan anak masuk sekolah dasar. Apabila Orang tua akan bekerja keras dalam mendidik anak-anak di rumah maka guru juga bekerja keras mendidik anak di lembaga pendidikan anak usia dini (Taman Kanak-Kanak). Kerjasama orang tua dan guru akan mengantarkan anak dalam kesiapan belajar untuk masuk sekolah dasar (SD/MI). 
Tabel 3. Demografis Responden Orang Tua

\begin{tabular}{|c|c|c|c|}
\hline No & Aspek & Jumlah & Persentase \\
\hline \multirow[t]{3}{*}{1} & Jenis kelamin & & \\
\hline & Perempuan & 69 & $79 \%$ \\
\hline & Laki-laki & 18 & $21 \%$ \\
\hline \multirow[t]{5}{*}{2} & Usia & & \\
\hline & $20-30$ & 58 & $67 \%$ \\
\hline & $31-40$ & 25 & $29 \%$ \\
\hline & $41-50$ & 3 & $3 \%$ \\
\hline & $51-60$ & 1 & $1 \%$ \\
\hline \multirow[t]{5}{*}{3} & Latar belakang pendidikan & & \\
\hline & S1 & 54 & $62 \%$ \\
\hline & D3 & 18 & $21 \%$ \\
\hline & SMA & 10 & $11 \%$ \\
\hline & SMP & 4 & $5 \%$ \\
\hline \multirow[t]{6}{*}{4} & Pekerjaan & & \\
\hline & Wiraswasta & 46 & $53 \%$ \\
\hline & PNS & 15 & $17 \%$ \\
\hline & Ibu Rumah Tangga & 14 & $16 \%$ \\
\hline & Petani & 11 & $13 \%$ \\
\hline & Buruh & 1 & $1 \%$ \\
\hline \multirow[t]{6}{*}{5} & Penghasilan & & \\
\hline & Rp. $500-1 \mathrm{jt}$ & 32 & $37 \%$ \\
\hline & Rp. $1,5-2$ jt & 18 & $21 \%$ \\
\hline & Rp. 2,5- 3 jt & 18 & $21 \%$ \\
\hline & Rp. 3,5-4 jt & 11 & $13 \%$ \\
\hline & Rp. $4,5-5$ jt & 8 & $9 \%$ \\
\hline \multirow[t]{9}{*}{6} & Instansi anak bersekolah & & \\
\hline & TK PGRI Timbulharjo & 15 & $17 \%$ \\
\hline & TK PGRI Kertamukti & 11 & $13 \%$ \\
\hline & TK Anugrah Panggungharjo & 7 & $8 \%$ \\
\hline & TK Intan Permata & 8 & $9 \%$ \\
\hline & TK PGRI Sidorahayu & 15 & $17 \%$ \\
\hline & TK PGRI Wonosari & 10 & $11 \%$ \\
\hline & TK PGRI Banyu Biru & 11 & $13 \%$ \\
\hline & TK PGRI Rengas Abang & 10 & $11 \%$ \\
\hline
\end{tabular}

\section{Peran Orang Tua}

Dalam aspek terkait peran orangtua, peneliti menggunakan 87 responden yang diambil dari 8 TK di lingkungan kecamatan Air Sugihan. Data demografis responden orang tua disajikan pada Tabel 3 berikut. Berdasarkan data pada Tabel 3, diketahui bahwa mayoritas responden yang terlibat berjenis kelamin perempuan dan hanya $21 \%$ dari responden berjenis kelamin laki-laki. Untuk aspek usia, secara umum lebih dari $60 \%$ responden berada dalam kategori usia sangat produktif muda (rentang usia antara 20-30 tahun). Adapun latar belakang pendidikan terkait dengan persentase yang hampir sama, didominasi oleh lulusan program strata 1, meskipun ada sebanyak 14 responden yang berada pada jenjang SMA dan SMP. Terkait dengan pekerjaan, sebanyak 53\% responden memiliki pekerjaan wiraswasta, dengan peringkat kedua disusul oleh PNS dan ibu rumah tangga. Untuk pendapatan atau penghasilan cukup bervariasi, meskipun peringkat pertama dengan 32 responden menyatakan bahwa penghasilan mereka berada pada kisaran Rp 500.000,00 (lima ratus ribu rupiah) sampai Rp 1.000.000,00 (satu juta rupiah). 
Untuk mengetahui gambaran dari peran orang tua dalam penyiapan masa transisi anak, peneliti menggunakan 6 konten pertanyaan yang disebarkan pada responden terkait dengan masalah perkembangan, dukungan orangtua, tindakan orangtua, harapan, hambatan, dan upaya peningkatan penyiapan masa transisi. Gambaran dari peran orangtua tersebut disajikan pada Tabel 4.

Tabel 4. Peran Orangtua

\begin{tabular}{|c|c|c|c|}
\hline No & Aspek & Jumlah & Persentase \\
\hline \multirow[t]{9}{*}{1} & Masalah perkembangan & & \\
\hline & Keterampilan akademis kurang & 16 & $18 \%$ \\
\hline & Perubahan lingkungan & 61 & $70 \%$ \\
\hline & Pendekatan pedagogis & 13 & $15 \%$ \\
\hline & Perkembangan pribadi anak & 28 & $32 \%$ \\
\hline & Perbedaan gender & 8 & $9 \%$ \\
\hline & Perubahaan kebiasaan rutin sehari-hari & 41 & $47 \%$ \\
\hline & Tingkat kepercayaan orangtua kepada anak & 26 & $30 \%$ \\
\hline & Dukungan orangtua dalam ketrampilan anak & 16 & $18 \%$ \\
\hline \multirow[t]{4}{*}{2} & Dukungan orangtua & & \\
\hline & Membeli buku & 35 & $40 \%$ \\
\hline & Terlibat dalam pemberian keterampilan akademis & 56 & $64 \%$ \\
\hline & Sering berbicara tentang sd & 61 & $70 \%$ \\
\hline \multirow[t]{5}{*}{3} & Tindakan orangtua & & \\
\hline & Pemberian perhatian & 69 & $79 \%$ \\
\hline & Meningkatkan kepercayaan diri anak & 59 & $68 \%$ \\
\hline & Menjelaskan sd kepada anak & 43 & $49 \%$ \\
\hline & Pemberian asupan gizi & 35 & $40 \%$ \\
\hline \multirow[t]{5}{*}{4} & Harapan & & \\
\hline & Kunjungan ke sekolah dasar & 26 & $30 \%$ \\
\hline & Komunikasi antara guru tk dan ortu terkait sd & 41 & $47 \%$ \\
\hline & Guru tk mengajarkan keterampilan akademis & 15 & $17 \%$ \\
\hline & Les tambahan & 43 & $49 \%$ \\
\hline \multirow[t]{5}{*}{5} & Hambatan & & \\
\hline & Tidak ada hambatan & 31 & $36 \%$ \\
\hline & Masalah kepribadian (perkawinan tidak harmonis)\ & 9 & $10 \%$ \\
\hline & Keuangan & 20 & $23 \%$ \\
\hline & Jadwal kerja & 39 & $45 \%$ \\
\hline \multirow[t]{5}{*}{6} & Upaya agar meningkatkan peran orangtua & & \\
\hline & Tidak tahu cara peningkatan peran orangtua & 9 & $10 \%$ \\
\hline & Program sekolah untuk orangtua & 38 & $44 \%$ \\
\hline & Mengikuti kegiatan parenting & 47 & $54 \%$ \\
\hline & Bantuan teknologi informasi dan komunikasi & 42 & $48 \%$ \\
\hline
\end{tabular}

Berdasarkan data pada aspek masalah perkembangan, sebanyak $70 \%$ responden menyatakan bahwa perubahan lingkungan menjadi masalah yang disepakati mempengaruhi masa transisi anak. Adapun perbedaan gender menjadi komponen paling sedikit mendapatkan persetujuan terkait menjadi sebuah masalah dalam masa transisi anak karena hanya 9\% (8 orangtua siswa) yang setuju akan hal tersebut. Terkait dengan dukungan orang tua, dua komponen hampir berbagi persentase yang sama besar (lebih dari 60\%) yaitu komponen terlibat dalam pemberian keterampilan akademis dan sering berbicara tentang sekolah dasar kepada anak-anak. Terkait dengan tindakan orang tua, pemberian perhatian dan peningkatan kepercayaan diri anak menjadi dua komponen teratas yang dilakukan orang tua untuk menyiapkan masa transisi anak mereka. Pada aspek harapan, peringkat 
terendah dinyatakan pada aspek harapan agar guru TK lebih mengajarkan keterampilan akademis kepada anak maka akan membantu anak dalam menghadapi masa transisi anak ke sekolah dasar, sedangkan komunikasi antara guru TK dan orangtua serta les tambahan memiliki persentase yang hampir sama. Terkait dengan aspek hambatan, secara berturut problema pertama yaitu jadwal kerja sangat berpengaruh terhadap peran orang tua dalam mendampingi dan mendukung anak dalam menghadapi masa transisi ke sekolah dasar, disusul oleh masalah keuangan dan kepribadian, meskipun pada peringkat kedua yaitu sebanyak $36 \%$ orangtua menyatakan tidak ada hambatan yang dialami dalam mendampingi dan mendukung anak dalam menghadapi masa transisi anak ke sekolah dasar. Pada aspek terakhir, hampir separuh responden menyatakan kesetujuannya terkait berbagai upaya peningkatan peran orangtua, dan hanya 9 responden yang menyatakan tidak tahu cara peningkatan peran orangtua.

Dari paparan di atas bisa terlihat gambaran peran orang tua selama masa transisi adalah objek yang paling penting karena dalam kehidupan anak, orang tua yang paling banyak memiliki pengetahuan dan pemahaman mendalam tentang perkembangan anak mereka. Keterlibatan orang tua yang erat memastikan bahwa para praktisi dapat mendapat informasi tentang anak-anak secara individu, termasuk masalah apa pun yang mungkin mereka miliki saat masa transisi. Kemitraan yang kuat juga memungkinkan orang tua dan praktisi untuk merencanakan bersama untuk mendukung transisi. Berbagai bentuk keterlibatan yang orang tua lakukan untuk mendukung pendidikan anak. Dalam proses persiapan orang tua harus mengetahui apa itu konsep dari kesiapan bersekolah. Hal tersebut sejalan dengan hasil penelitian dari Marwiyati \& Istiningsih (2020) yang menunjukkan orangtua sangat berperan penting dalam kesiapan sekolah anak yaitu bertanggungjawab terhadapan kesiapan sekolah anak, memotivasi, sebagai role model,sebagai pengawas dan sebagai konselor sehingga semua kebutuhan dalam kesiapan sekolah anak terpenuhi.

Menurut Britto (2012) kesiapan sekolah didefinisikan dengan dua karakteristik dan pada tiga dimensi. Karakteristik pertama adalah 'transisi' dan yang kedua adalah 'mendapatkan kompetensi', dan tiga dimensi yang dimaksud antara lain: (1) anak-anak yang siap, fokus pada pembelajaran dan perkembangan anak-anak, (2) sekolah siap pakai, dengan fokus pada lingkungan sekolah bersama dengan praktik-praktik yang mendorong dan mendukung transisi yang lancar untuk anak-anak ke sekolah dasar dan memajukan serta mempromosikan pembelajaran semua anak, dan (3) keluarga siap pakai, dengan fokus pada sikap dan keterlibatan orang tua dan pengasuh dalam pembelajaran dan pengembangan awal anak-anak mereka dan transisi ke sekolah. Dan yang ketiga dimensi itu penting dan harus bekerja bersama-sama, karena kesiapan sekolah adalah masa transisi yang membutuhkan antarmuka antara individu, keluarga, dan sistem.

Harper (2016) memaparkan terdapat cara yang bisa diterapkan oleh orang tua untuk menyiapkan masa transisi anak mereka yaitu meliputi lima komponen. Komponen pertama yaitu 
terkait pembuatan jadwal bermain, pelibatan anak-anak dalam diskusi keluarga, komponen ketiga terkait dengan membangun dukung apabila ada masalah, komponen keempat yaitu terkait aturan praktik, rutinitas, dan jadwal, pengalaman anak-anak di rumah mempengaruhi persiapan, transisi, dan keterlibatan mereka di sekolah, dan komponen kelima yaitu menjadi advokat bagi anak. Berikut merupakan pemaparan dari kelima komponen yang telah dijabarkan sebelumnya.

Pertama, terkait pembuatan jadwal pengalaman bermain, anak-anak harus mempunyai pengalaman sosial yang banyak dengan anak-anak disekitar agar bisa bermain atau terlibat secara rutin berolahraga atau minat anak. Pengalaman-pengalaman ini membangun kompetensi sosial anak-anak yang diperlukan untuk menjalin rasa persahabatan dan hubungan baru dengan teman sebaya, serta mengekspos mereka kepada beragam anak, orang dewasa, struktur keluarga, dan budaya yang beragam. Kompetensi sosial membantu membuka jalan bagi anak-anak untuk menjalin antar sahabat dan hubungan dengan anak-anak lain (Dennis \& Stockall, 2015). Penelitian yang membahas penyesuaian anak-anak muda ke situasi sekolah baru menunjukkan bahwa anak-anak yang dapat melakukan transisi dengan lancar berbagi beberapa kemampuan penting mereka mampu 1) berinteraksi bersama teman sebaya dengan positif dan berkelompok, 2) terlibat dalam permainan khayalan yang melibatkan peran kooperatif, 3) berhasil memasuki permainan anak-anak lain, 4) berbicara dengan teman sebaya secara langsung, 5) memusatkan perhatian mereka pada orang lain dalam situasi kelompok, dan 6) menanggapi inisiasi orang lain (O’Kane, 2016).

Komponen kedua yaitu penting untuk melibatkan anak-anak dalam diskusi keluarga (terutama rute dan moda transportasi ke sekolah dan sekolah dan harapan guru), membuka pintu diskusi bagi anak-anak untuk secara rutin dalam mengungkapkan keprihatinan mereka dengan cara melakukan diskusi keluarga tentang transisi yang diantisipasi termasuk harapan mereka, ketakutan mereka dan hal-hal yang tidak diketahui terkait. Ketakutan umum yang biasanya dialami oleh anak-anak sebelum mulai sekolah mencakup perincian tentang bagaimana mereka akan sampai di sekolah dan kembali ke rumah, serta peraturan sekolah dan keinginan guru. Meluangkan waktu untuk mengeksplorasi pemikiran anak Anda tentang dua hal ini dapat mengurangi kecemasan anak dan memberikan sedikit jaminan sebelum transisi. Orang tua juga harus meninjau rute ke sekolah dan moda transportasi yang digunakan bersama anak mereka sebelum hari pertama anak sekolah. Membuat peta untuk mengilustrasikan rute dari rumah anak ke sekolah anak adalah kegiatan interaktif yang luar biasa yang dapat memicu percakapan terkait transportasi sambil mengurangi ketakutan mendasar anak tentang hal yang tidak diketahui. Untuk memberikan jaminan dan dukungan kepada anak, keluarga dapat melibatkan anak dalam percakapan yang menerangi rute ini dan kemudian mengarahkan rute bersama, meminta anak untuk menjadi navigator. Anggota keluarga dapat menunjukkan petunjuk di sepanjang rute sambil menghitung berapa lama untuk tiba di sekolah dari rumah. Jika anak tersebut akan diturunkan di suatu tempat selain rumah setelah 
sekolah, informasi ini dapat didiskusikan juga. Dengan melibatkan anak-anak dalam diskusi keluarga, orang tua dapat memberikan kesempatan bagi anak-anak untuk mengungkapkan keprihatinan mereka dan bekerja untuk mengatasinya di tahap awal transisi.

Komponen ketiga yaitu membangun dukung, apabila anak-anak mengalami masalah tertentu, hubungannya dengan konteks yang bisa mendukung dan membantu dari masalah yang terjadi yang mana masalah ini dapat dikomunikasikan. Komunikasikan bersama anak anda mengenai siapa yang bisa mereka andalkan untuk berbicara tentang tantangan dan kemenangan di sekolah baik di sekolah maupun di rumah. Sementara seorang anak biasanya meminta bantuan orang tua terlebih dahulu, bantulah anak Anda dalam memahami bahwa dukungan bisa didapatkan dari banyak orang lain, misalnya anggota keluarga lain dan staf yang berada di lingkungan sekolah. Dalam membantu anakanak agar terbangun sistem yang akan mengurangi kecemasan tentang apa yang harus dilakukan jika seorang anak membutuhkan bantuan dan ke mana harus mencari dukungan jika kebutuhan itu muncul. Transisi yang berhasil ke sekolah sebagian besar bersandar pada pembentukan hubungan yang positif dan suportif dan faktor yang berkontribusi terhadap kesiapan sekolah anak-anak (Correia \& Marques-Pinto, 2016).

Komponen keempat yaitu terkait aturan praktik, rutinitas, dan jadwal, pengalaman anak-anak di rumah mempengaruhi persiapan, transisi, dan keterlibatan mereka di sekolah. Penelitian menunjukkan bahwa sumber daya yang disediakan di rumah (Kiernan \& Mensah, 2011), rutinitas di rumah (Wildenger dkk., 2008), dan sifat lingkungan belajar di rumah adalah prediktor kuat hasil pendidikan dan perilaku untuk anak-anak selama tahun-tahun sekolah dasar (Melhuish dkk., 2008). Mungkin yang paling penting, keluarga dapat menetapkan dan mempraktikkan aturan, rutinitas, dan jadwal dengan anak mereka sebelum mulai sekolah. Meskipun sebagian besar anak yang pindah ke sekolah memiliki rutinitas yang teratur, sebuah studi menunjukkan bahwa sebagian besar anak-anak mungkin kurang dapat diprediksi, jadwal yang terorganisir selama periode penyesuaian yang penting ini (Wildenger dkk., 2008). Untuk membantu anak menyesuaikan dengan peraturan dan rutinitas sekolah, keluarga dapat mengidentifikasi, membangun, dan mempraktikkan rutinitas terkait sekolah di rumah. Rutinitas mungkin termasuk menggantung mantel dan ransel di tempat yang sama setiap hari, memilih dan meletakkan pakaian sebelum tidur di malam hari dan membaca bersama setiap malam.

Peluang khusus untuk membahas transisi yang akan datang mungkin muncul dari membaca buku cerita bergambar tentang transisi ke sekolah. Banyak perpustakaan setempat memiliki daftar yang ditujukan untuk 'hari pertama sekolah' untuk membantu memicu diskusi antara anak-anak dan keluarga. Rutinitas ini akan terbawa ke rutinitas sekolah, mengurangi kecemasan dan stres, dan memperlancar transisi untuk anak-anak dan keluarga mereka. Menyesuaikan dan memelihara jadwal kegiatan anak di rumah 2 minggu sebelum masuk sekolah dapat meningkatkan transisi yang lancar 
untuk anak-anak dan orang tua. Waktu tidur dapat disesuaikan, dipraktikkan, dan dipelihara. Waktu bangun dan rutinitas sarapan juga dapat ditetapkan dan dipraktikkan pada hari-hari sebelum masuk sekolah. Mematuhi jadwal ini akan mempersiapkan anak-anak untuk transisi ke sekolah, menjadikannya lebih lancar bagi semua yang berkepentingan.

Pendekatan kelima yaitu menjadi advokat untuk anak-anak, selain membagikan apa yang mereka ketahui tentang anak mereka dengan guru, berkomunikasi secara teratur dengan guru anak mereka, dan tetap terlibat dengan sekolah anak mereka, keluarga dapat menjadi pendukung untuk anak-anak. Mereka dapat meminta pertanggungjawaban sekolah atas apa yang mereka katakan mereka lakukan dalam pernyataan misi mereka. Orang tua dapat mengetahui hak-hak pendidikan anak mereka dan kebijakan sekolah, jaringan dengan orang tua lainnya, atau terlibat dalam kampanye lokal, masalah negara atau kebijakan federal. Keluarga dapat mengurangi kecemasan dan stres sehingga memperlancar transisi dengan menjadi pendukung yang efektif untuk anak-anak mereka dan orang lain dalam proses tersebut. Masuk ke sekolah baru dapat menjadi waktu perubahan dramatis bagi orang tua serta anak-anak dan anggota keluarga lainnya. Kekhawatiran tentang pemisahan dari anak mereka, aspek keselamatan dan perawatan dari pengaturan baru, dan frekuensi komunikasi yang diberikan oleh guru baru, dikombinasikan dengan masalah budaya atau bahasa dapat menyebabkan kecemasan pada beberapa orang tua. Kecemasan ini dapat dengan mudah ditularkan secara tidak langsung ke anak. Namun, keluarga dapat mengambil sikap proaktif dan membantu anak-anak mengembangkan strategi untuk mendekati lingkungan dan situasi baru, mengatasi perubahan, dan menyelesaikan masalah sebelum masuk sekolah, sehingga membantu mereka membangun fondasi yang kuat untuk masa depan pendidikan mereka.

\section{SIMPULAN DAN SARAN}

\section{Simpulan}

Masa transisi adalah suatu perubahan atau peralihan baik secara kondisi, tempat atau keadaan dari fase lama ke baru. Dari hasil penelitian menunjukkan perkembangan anak yang belum optimal serta perubahan lingkungan merupakan masalah utama yang sering terjadi dikalangan anak yang baru memasuki sekolah dasar khususnya pada jenjang kelas satu. Peran guru SD, guru TK dan orang tua sangat penting untuk mendukung dan membantu anak dalam menghadapi masa transisi ke sekolah dasar. Peran tersebut adalah dengan melibatkan atau ikut berpartisipasi dalam masa transisi anak seperti adanya kerjasama antar guru SD dan guru TK untuk memberikan laporan perkembangan anak, menerima atau mengadakan kunjungan antar sekolah (baik SD atau TK), melibatkan orangtua dalam memberikan dukungan kepada anak dan adanya program masa transisi dari masing-masing sekolah. 


\section{Saran}

Perlu adanya kerjasama antara guru dari kedua lembaga (TK \& SD) dan kebijakan pemerintah dalam memperhatikan masa transisi anak agar perkembangan anak optimal dalam menghadapi masa transisinya ke sekolah dasar. Bagi pemerintah disarankan untuk membuat kebijakan berupa buku panduan atau program yang mendukung masa transisi anak dari Taman Kanak-Kanak ke Sekolah Dasar guna untuk mempermudah sekolah dalam mempersiapkan masa transisi anak ke sekolah dasar.

\section{DAFTAR RUJUKAN}

Angel, M., \& Garcia, U. (2014). Transition from Preschool to First Grade Primary School in Mexico: The Perceptions of Teachers, Headteachers and Parents. October, 1-307.

Barth, J. M., \& Parke, R. D. (1993). Parent-child relationship influences on children's transition to school. Merrill-Palmer Quarterly (1982-), 173-195.

Burns, A., \& Homel, R. (1989). Gender division of tasks by parents and their children. Psychology of Women Quarterly, 13(1), 113-125.

Correia, K., \& Marques-Pinto, A. (2016). Adaptation in the transition to school: Perspectives of parents, preschool and primary school teachers. Educational Research, 58(3), 247-264.

Cote, L. R., \& Azar, S. T. (1997). Child age, parent and child gender, and domain differences in parents' attributions and responses to children's outcomes. Sex Roles, 36(1-2), 23-50.

Damayanti, A. K., \& Rachmawati, R. (2019). Kesiapan Anak Masuk Sekolah Dasar Ditinjau Dari Tingkat Intelegensi dan Jenis Kelamin. PSIKOVIDYA, 23(1), 108-137.

Deliviana, E. (2017). Mempersiapkan Anak Masuk Sekolah Dasar. Jdp, 10(2), 119-133.

Dennis, L. R., \& Stockall, N. (2015). Using play to build the social competence of young children with language delays: Practical guidelines for teachers. Early Childhood Education Journal, 43(1), 1-7.

Dockett, S., \& Perry, B. (2004). What makes a successful transition to school? Views of Australian parents and teachers. International journal of early years education, 12(3), 217-230.

Garcia, M. A. U. (2014). Transition from Preschool to First Grade Primary School in Mexico: The Perceptions of Teachers, Headteachers and Parents [PhD Thesis]. University of York.

Harper, L. J. (2016). Supporting Young Children's Transitions to School: Recommendations for Families. Early Childhood Education Journal, 44(6), 653-659. https://doi.org/10.1007/s10643-015-0752-z

Hartlep, N., \& Ellis, A. (2010). Are Household Income, Gender, and Race Important in Shaping Parental Involvement in Children's Education?. Online Submission.

Islamy, I. (2019). Penelitian Survei dalam Pembelajaran \& Pengajaran Bahasa Inggris. Pasca Sarjana Pendidikan Bahasa Inggris, August.

Jafarov, J. (2015). Factors Affecting Parental Involvement in Education: The Analysis of Literature. Khazar Journal of Humanities and Social Sciences, 18(4), 35-44. https://doi.org/10.5782/2223-2621.2015.18.4.35

Kiernan, K. E., \& Mensah, F. K. (2011). Poverty, family resources and children's early educational attainment: The mediating role of parenting. British Educational Research Journal, 37(2), 317 336.

Kocayörük, E. (2016). Parental Involvement and School Achievement. International Journal of Human and Behavioral Science, 2(2). https://doi.org/10.19148/ijhbs.65987

Lau, E. Y. H., Li, H., \& Rao, N. (2012). Exploring parental involvement in early years education in China: Development and validation of the Chinese Early Parental Involvement Scale (CEPIS). International Journal of Early Years Education, 20(4), 405-421. https://doi.org/10.1080/09669760.2012.743099

Lubbe, C. (2007). To tell or not to tell: How children of same-gender parents negotiate their lives at school. Education as Change, 11(2), 45-65. 
Magwa, S., \& Mugari, S. (2017). Factors Affecting Parental Involvement in the Schooling of Children. International Journal of Research and Reflection, 5(1), 74-81.

Marwiyati, S., \& Istiningsih, I. (2020). Pembelajaran Saintifik pada Anak Usia Dini dalam Pengembangan Kreativitas di Taman Kanak-Kanak. Jurnal Obsesi : Jurnal Pendidikan Anak Usia Dini, 5(1), 135-149. doi:https://doi.org/10.31004/obsesi.v5i1.508

McDowell, K., Jack, A., \& Compton, M. (2018). Parent Involvement in Pre-Kindergarten and the Effects on Student Achievement. The Advocate, 23(6). https://doi.org/10.4148/2637-4552.1004

Melhuish, E. C., Phan, M. B., Sylva, K., Sammons, P., Siraj-Blatchford, I., \& Taggart, B. (2008). Effects of the home learning environment and preschool center experience upon literacy and numeracy development in early primary school. Journal of Social Issues, 64(1), 95-114.

Muntoni, F., \& Retelsdorf, J. (2019). At their children's expense: How parents' gender stereotypes affect their children's reading outcomes. Learning and Instruction, 60, 95-103.

Nurhayati, W. (2018). Transisi ke sekolah dasar dan kesiapan bersekolah: Studi eksplorasi pada orang tua. National Conference on Educational Assessment and Policy, Nceap.

O'Kane, M. (2016). Transition from preschool to primary school. Dublin: National Council for Curriculum and Assessment.

Pia Rebello Britto, A. J. R. and C. W. (2012). School readiness. Dalam School Readiness A Conceptual Framework. https://doi.org/10.2307/1602361

Pirskanen, H., Jokinen, K., Karhinen-Soppi, A., Notko, M., Lämsä, T., Otani, M., Meil, G., RomeroBalsas, P., \& Rogero-García, J. (2019). Children's Emotions in Educational Settings: Teacher Perceptions from Australia, China, Finland, Japan and Spain. Early Childhood Education Journal, 47(4), 417-426. https://doi.org/10.1007/s10643-019-00944-6

Rahmawati, A., Tairas, M. M. W., \& Nawangsari, N. A. F. (2018). Profil kesiapan sekolah anak memasuki sekolah dasar. Jurnal Pendidikan Usia Dini, 12(2), 201-210.

Rifai, M., \& Fahmi. (2017). Pengelolaan kesiapan belajar anak masuk sekolah dasar. Tarbawi, 3(01), 129-143. http://dx.doi.org/10.32678/tarbawi.v3i01.1784

Solfiah, Y. (2020). Perbedaan Tujuan Kesiapan Sekolah Antara Guru Taman Kanak-. 15-19.

Sulistyaningsih, W., \& Haditono, S. R. (1998). Kesiapan bersekolah ditinjau dari jenis pendidikan prasekolah anak dan tingkat pendidikan orang tua [PhD Thesis]. [Yogyakarta]: Universitas Gadjah Mada.

Wildenger, L. K., McIntyre, L. L., Fiese, B. H., \& Eckert, T. L. (2008). Children's daily routines during kindergarten transition. Early Childhood Education Journal, 36(1), 69-74.

Yu, Y. H., Hu, Y. N., \& Zhang, J. S. (2013). A research on reading model of interactive children picture book application based on the theory of "zone of proximal development." Applied Mechanics and Materials, 411-414(4), 2952-2956. https://doi.org/10.4028/www.scientific.net/AMM.411-414.2952 